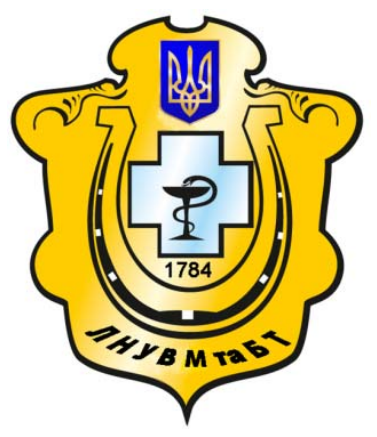

Науковий вісник Львівського національного університету ветеринарної медицини та біотехнологій імені С.3. Гжицького

Scientific Messenger of Lviv National University of Veterinary Medicine and Biotechnologies named after S.Z. Gzhytskyj

doi:10.15421/nvlvet6640

ISSN 2413-5550 print

ISSN 2518-1327 online

http://nvlvet.com.ua/

УДК 619: 636.2: 577: 616.36

\title{
Редокс-потенціал та стан перекисного окиснення ліпідів крові корів, що утримуються у екологічно несприятливих умовах
}

\author{
І.В. Чала, В.С. Русак \\ v.s.rusak@gmail.com

\begin{abstract}
Житомирський начіональний агроекологічний університет, вул. Корольова, 39, м. Житомир, 10025, Україна
\end{abstract}

\begin{abstract}
Стаття присвячена дослідженню дії комплексу несприятливих екологічних факторів, щьо склалися у результаті забруднення сільськогосподарських угідь у результаті аварії на Чорнобильській АЕС, на інтенсивність перекисного окиснення ліпідів та глутатіонової ланки антиоксидантної системи молочних корів та на зміни редокс-потенціалу крові. На території, ще зазнала забруднення радіонуклідами чорнобильського походження склалась несприятлива екологічна ситуація, яка пов'язана із збільшенням радіоактивного навантаження на тварин, зменшення частки розчинної (обмінної) форми біогенних мінеральних елементів трунтів. За таких умов інічіюється комплекс біохімічних змін, викликаних радіолізом води, збільшенням активних форм кисню та захистом організму від продуктів пере окислення, щзо утворюються у результаті діі продуктів радіолізу. Метою досліджень було визначення редокс-потенціалу венозної крові та окремих показників перекисного окиснення ліпідів та антиоксидантної системи крові корів, які утримувались у зоні, забрудненій радіонуклідами техногенного походження порівняно до таких, що утримувались у зоні з фоновими значеннями радіоактивності та потужності ү-випромінювання. У результаті досліджень встановлено, що у крові корів, які утримувались у екологічно несприятливих умовах, збільшується концентрація продуктів перекисного окиснення ліпідів: гідроперекисів ліпідів, малонового діальдегіду. За ичих умов встановлено зміни активності глутатіонової ланки антиоксидантної системи: зменшення частки відновленого глутатіону та достовірне збільшення частки окисленого глутатіону, зменшення активності ферменту глутатіонредуктази порівняно до таких у корів, щео утримувались у екологічно благополучних умовах. Встановлено, щуо в умовах діі несприятливих екологічних факторів зростає позитивний редокс-потенціал крові, щэо свідчить про порушення між окисленими та відновними потенціалами.
\end{abstract}

Ключові слова: радіонукліди, корови ,кров, перекисне окиснення ліпідів, гідроперекиси ліпідів, малоновий діальдегід, антиоксидантна система, відновлений глутатіон, окислений глутатіон, глутатіонредуктаза, редокс-потенціал.

\section{Редокс-потенциал и состояние перекисного окисления липидов крови коров, содержащихся в екологічески неблагоприятных условиях}

\author{
И.В. Чалая, В.С. Русак \\ v.s.rusak@gmail.com
}

\begin{abstract}
Житомирский начиональный агроэкологический университет, ул. Королева, 39, г. Житомир, 10025, Украина
\end{abstract}

\begin{abstract}
Статья посвящена исследованию действия комплекса неблагоприятных экологических факторов, сложившихся в результате загрязнения сельскохозяйственных угодий в результате аварии на Чернобыльской АЭС, на интенсивность перекисного окисления липидов и глутатионового звена антиоксидантной системи молочных коров и на изменения редокспотенциала крови. На территории, загрязненной радионуклидами чернобыльского происхождения, сложилась неблагоприятная экологическая ситуачия, связанная с увеличением радиоактивной нагрузки на животных, уменьшением доли растворимой (обменной) формы биогенных минеральных элементов почвы. В таких условиях иничиируется комплекс биохимических изменений, вызванных радиолизом воды, увеличением активных форм кислорода и защитой организма от продуктов
\end{abstract}

Citation:

Chala, I.V., Rusak, V.S. (2016). Redox-potential and the state of peroxide oxidation of blood lipids in cows kept under ecologically unfavorable conditions. Scientific Messenger LNUVMBT named after S.Z. Gzhytskyj, 18, 2(66), 197-201. 
переокисления, образующихся в результате действия продуктов радиолиза. Целью исследований было определения редокспотениала венозной крови и отдельных показателей перекисного окисления липидов и антиоксидантной системь крови коров, содержащчихся в зоне, загрязненной радионуклидами техногенного происхождения по сравнению с содержащимися в зоне с фоновыми значениями радиоактивности и мощности ү-излучения. В результате исследований установлено, что в крови коров, содержащихся в экологически неблагоприятных условиях, увеличивается концентрация продуктов перекисного окисления липидов: гидроперекисей липидов, малонового диальдегида. Установлены изменения активности глутатионового звена антиоксидантной системь: уменьшение доли восстановленного глутатиона и достоверное увеличение доли окисленного глутатиона, уменьшение активности фермента глутатионредуктазы по сравнению с такими у коров, содержашихся в экологически благоприятных условиях. Установлено, что в условиях действия неблагоприятных экологических факторов увеличивается положительный редокс-потенцииал крови, что свидетельствует о наруиении между окисленными та восстановленными потенциилами.

Ключевье слова: радионуклиды, коровы, кровь, перекисное окисления липидов, гидроперекиси липидов, малоновый диальдегид, антиоксидантная система, восстановленный глутатион, окисленный глутатион, глутатионредуктаза, редокс-потенциил.

\title{
Redox-potential and the state of peroxide oxidation of blood lipids in cows kept under ecologically unfavorable conditions
}

\author{
I.V. Chala, V.S. Rusak \\ v.s.rusak@gmail.com \\ Zhytomyr National Agroecological University, \\ Korolova str., 39, Zhytomyr, 10025, Ukraine
}

\begin{abstract}
The paper highlights the investigations into the effects of the complex of unfavorable ecological factors which appear as a result of Chernobyl-derived contamination of farm lands on the intensity of peroxide oxidation of lipids and glutathione chain of the antioxidant system of dairy cows, as well as on the changes in the redox-potential of blood. The territory that suffered from Chernobylderived radionuclide contamination is characterized by the unfavorable ecological situation which is connected with the increase in the radioactive load on animals, as well as with the decrease in the part of soluble (exchange) form of biogenic mineral elements of soils. The above conditions make it possible to initiate a complex of biochemical changes caused by water radiolysis, by the increase in the active forms of oxygen and by the protection of the body from the products of peroxidation which appear as a result of the effects of radiolysis products. The investigation is aimed at determining the redox-potential of venous blood and separate indices of the peroxide oxidation of lipids and the antioxidant system of blood in cows kept in the zone which was contaminated by the mancaused radio nuclides, as compared with cows kept in the zone with background values of radioactivity and $j$ irradiation emissive power. The investigation results make it possible to establish that in the blood of cows kept under ecologically unfavorable conditions one can observe the increase in the concentration of the products of lipid peroxide oxidation: hydroperoxide lipids and malone dialdehyde. Under the above conditions one can establish the changes in the activity of the glutathione chain of the antioxidant system: the decrease in the part of renewed glutathione and the authentic increase in the part of oxidized glutathione and the decrease in the activity of glutathione reductase as compared with cows kept under ecologically favorable conditions. It has been established that under the effects of unfavorable ecological factors one can observe the increase in the positive redox-potential of
\end{abstract} blood which testifies to the disturbances between oxidized and renewed potentials.

Key words: radionuclides, cows, blood, peroxide oxidation of lipids, hydroperoxyde of lipids, malone dialedhyde, antioxidant system, renewed glutathione, oxidized glutathione, glutathione reductase, redox-potential.

\section{Вступ}

У зв'язку із постійним зростанням екологічної напруженості збільшується вплив ксенобіотиків на обмінні процеси у сільськогосподарських тварин, що потребує подальшого грунтовного дослідження механізмів вказаного впливу. Зокрема, після аварії на ЧАEC у 1986 значна частина сільськогосподарських угідь України була забруднена радіонуклідами, i, хоча після техногенної катастрофи минуло більше тридцяти років і за цей час розпалося близько половини радіонуклідів, частина радіоактивних елементів, що залишилась у грунтово-поглинальному комплексі, поступово перейшла у обмінну форму, доступну для рослин, що у свою чергу, призвело до їх включення у трофічні ланцюги, і як результат, до накопичення у тваринних організмах. Окрім досліджень, направлених на з'ясування особливостей накопичення радіонуклідів у організмі тварин у залежності від різноманітних факторів, важливим є дослідження молекуляр- них механізмів впливу радіонуклідів на хімічні процеси у тканинах. Так, одним із стартових і універсальних біохімічних процесів, які виникають при дії ксенобіотиків, у тому числі, радіонуклідів, а також при розвитку патологічних процесів, $є$ перекисне окиснення ліпідів, що суттєво змінює стан окисновідновних процесів у клітинах, змінює структуру клітинних мембран. Оскільки при дії доз опромінення, близьких до фонових, фундаментальним процесом $\epsilon$ радіоліз води, у результаті якого утворюється ряд активних радикалів, зокрема супероксидрадикал (СОД), який призводить до розвитку каскаду хімічних перетворень, а саме перекисного окиснення ліпідів (ПОЛ), утворення атипових форм поліпептидів тощо (Filipenko, 1996). Накопичення перекисів та інших продуктів окиснення речовин суттєво змінює співвідношення між потенціалами відновлення та окиснення. Одним 3 критеріїв оцінки стану окисно-відновних процесів у тканинах тварин $є$ редокс-потенціал. Редокс-потенціал (окисно-відновий потенціал, $\mathrm{E}_{\mathrm{h}}$ ) - 
показник, що характеризує здатність речовини (біологічної рідини, розчину) приєднувати електрони, тобто відновлюватись. Редокс - потенціал крові клінічно здорових тварин: артеріальної - мінус 57 мВ, венозної - мінус 7 мB, за умов розвитку патологічних процесів редокс-потенціал суттєво змінюється, найбільші позитивні значення даного показника реєструються за онкологічних патологій, зміни величини редокспотенціалу призводять до порушення поляризації клітинних мембран, порушень структури ферментів, у першу чергу ферментів класу оксидоредуктаз, які забезпечують метаболізм макроергів.

Оскільки перекисне окиснення ліпідів є процесом притаманним для клінічно здорових тварин і за звичайних умов направлене на руйнування та видалення пошкоджених, «застарілих» молекул жирних кислот та інших хімічних сполук, знешкодження активних форм кисню (АФК), то відповідно функціонує система захисту від надмірної концентрації вільних радикалів кисню, продуктів ПОЛ та інших метаболітів 3 високою здатністю приєднувати електрони, - це антиоксидантна система (АОС) тварин. Антиоксидантна система включає декілька функціонально взаємозв'язаних ланок: антирадикальну, антиперекисну та ферментативну. Остання представлена групою ферментів та субстратів, які каталізують відщеплення протонів Гідрогену та електронів і перенесення їх на окислені продукти, найбільш поширеною і потужною $\epsilon$ глутатіонова система, яка включає дві фракції глутатіону: окислений і відновлений та ферменти глутатіоноксидазу (КФ 1.11.1.9), глутатіонредуктазу (КФ 1.8.1.7) (Anderson and Meister, 1989; Muhutdinova, 2015). Таким чином, дослідження окремих показників стану ПОЛ і АОС, а також редокс-потенціалу, який у певній мірі відображає функціональні зв'язки між цими системами у тварин, що знаходяться у зоні, забрудненій радіонуклідами, має важливе наукове та практичне значення (Rusak and Chala, 2015).

Метою досліджень було визначення редокспотенціалу венозної крові та окремих показників ПОЛ i АОС у крові корів, які утримувались у зоні, забрудненій радіонуклідами техногенного походження порівняно до таких, що утримувались у зоні з фоновими значеннями радіоактивності та потужності $\gamma$ випромінювання.

Завданнями досліджень було визначення редокспотенціалу крові корів, що знаходились у різних екологічних умовах, визначення концентрації продуктів ПОЛ - гідроперекисів ліпідів (ГПЛ) та малонового діальдегіду. Важливим завданням було встановлення можливостей організму тварин протидіяти надмірному накопиченню окислених продуктів, а саме активності глутатіонової ланки антиоксидантної системи: визначення активності ферменту глутатіонредуктази та концентрації окисленої та відновленої фракцій глутатіону.

\section{Матеріал і методи досліджень}

Для досліджень було сформовано дві групи молочних корів по 10 голів у кожній за принципом аналогів за живою масою, віком, стадією лактації та молоч- ною продуктивністю. Тварини контрольної групи утримувались у господарстві ТОВ «Агросервіс» с. Івниця Андрушівського району Житомирської області, $\gamma$-фон на території господарства становив 12 мкР/год, радіоактивність добового раціону корів за ${ }^{137} \mathrm{Cs}-800-1500$ Бк/добу. Тварини дослідної групи утримувались у ТОВ «Полісся», с. Сілець, Народицького району Житомирської області, $\gamma$-фон становив 22 - 25 мкР/год, радіоактивність добового раціону за ${ }^{137} \mathrm{Cs}-8-10$ кБк/добу. Для досліджень відбирали кров 3 яремної вени 3 дотриманням правил асептики та антисептики. Нативну кров стабілізували цитратом натрію. Вміст загального та відновленого глутатіону визначали спектрофотометричним методом 3 реактивом Еллмана (5,5-дітіо-біс-(2-нітробензойною кислотою) (Kondrahin, 2004), концентрацію гідроперекисів ліпідів - спектрофотометричним методом (Gavrilov and Mishkorudnaya, 1983), концентрацію малонового діальдегіду - у реакції с тіобарбітуровою кислотою (Gavrilov et al., 1987), активність глутатіонпероксидази - фотометричним методом у реакції окиснення бензидину пероксидом водню (Anderson and Meister, 1989). Редокс-потенціал крові визначали методом потенціометрії іономіром лабораторним I-160MI 3 використанням індикаторного електроду ЕРП-101, у середовищі 3 моль/л хлориду калію, застосовували електролітичний ключ для мікродоз. Одержані результати статистично опрацьовували з використанням критерію Стюдента.

\section{Результати та їх обговорення}

Утримання корів у зоні, забрудненій радіонуклідами, призводить до накопичення у тканинах тварин радіонуклідів, які у результаті радіоактивного розпаду виділяють енергію (у вигляді $\gamma$-квантів або радіоактивних частинок), яка здатна ініціювати процеси радіолізу води. Аналогічні процеси відбуваються і у тварин, що знаходяться на утриманні у екологічно благополучних умовах, однак інтенсивність і щільність випромінювання - різні, поряд з цим, у зоні, що зазнала радіоактивного забруднення, у 90-х роках проводився комплекс агротехнічних заходів, направлених на переведення радіонуклідів у нерозчинний стан, ці заходи призвели і до зменшення у грунті частки обмінної форми багатьох біологічно важливих мінеральних елементів, що, відповідно, і зменшило їх надходження у кормові рослини. Дефіцит мінеральних елементів та інших біологічно активних нутрієнтів призвело до напруженості обмінних процесів у організмі тварин, що утримуються у забрудненій зоні. Таким чином, виокремити дію радіоактивної складової за даних умов не можливо, на даний момент констатується сукупна дія цілої низки несприятливих екологічних факторів.

Результати дослідження стану перекисного окиснення ліпідів та активності антиоксидантної системи представлені у таблиці.

Як видно 3 наведених результатів, у крові корів дослідної групи спостерігається зростання накопичення продуктів перекисного окиснення ліпідів порівняно до дослідної групи, зокрема концентрація гід- 
роперекисів ліпідів (ГПЛ) у тварин дослідної групи зросла на 48,4\% порівняно до такої у корів контрольної групи, концентрація малонового діальдегіду, одного 3 самих стійких продуктів ПОЛ у крові корів дослідної групи збільшувалась на 48\%. Щодо показників стану глутатіонової ланки антиоксидантної системи, то концентрація загального глутатіону у корів дослідної групи була на 7,6\% більшою, ніж у контролі (p > 0,05), тоді як частка відновленої фракції, навпаки, на 73\% була більшою у корів контрольної групи, частка окисленого глутатіону у корів дослідної групи достовірно зростала на 79\% (p < 0,05). Вказані зміни свідчать про надмірну витрату відновленого глутатіону, який здатний віддавати протони гідрогену та електрони для здійснення відновлення ГПЛ, перекису водню. Значна втрата відновленого глутатіону може негативно впливати на хід окисно-відновних реакцій в організмі в цілому. Як відомо, функції глутатіонової системи не обмежуються участю у процесах відновлення продуктів ПОЛ, глутатіонова система $\epsilon$ універсальною відновною системою і використовується для відновлення сульфгідрильних груп активних центрів багатьох ферментів, що забезпечують процеси життєдіяльності тваринного організму (Anderson and Meister, 1989; Muhutdinova, 2015). Оскільки вміст загального глутатіону дещо більший у тварин дослід- ної групи, то таке збільшення, можливо, є компенсаторним механізмом. Для збільшення відновного потенціалу клітин важливим $є$ не лише вміст глутатіону (субстрату даної системи), а і ферментів, що забезпечують постійність концентрації фракцій глутатіонової системи: глутатіоноксидази, глутатіонредуктази, глутатіонтрансферази. Активність одного 3 ключових ферментів системи глутатіонредуктази, що каталізує відновлення окисленої форми та перетворення у відновну, у корів дослідної групи була на 23,2\% нижчою, ніж у дослідній групі. Зниження активності даного ферменту може бути обумовлене багатьма факторами, одним з яких є можливий дефіцит Селену у раціоні корів дослідної групи. Селен $є$ небілковою частиною вказаного ферменту, тому навіть за умов достатнього синтезу апоферменту і дефіциту мікроелементу, активність глутатіонредуктази буде знижуватись. Як вище зазначалось, на територіях, забруднених радіонуклідами, склалась ситуація, за якої частка обмінної форми багатьох мінеральних елементів зменшилась, а отже і зменшилась їх міграція трофічними ланцюгами. Зменшення активності даного ферменту вимагає від тваринних тканин компенсаторного синтезу нових молекул глутатіону, що потребує витрат енергетичних та пластичних резервів організму.

Показники перекисного окиснення ліпідів, антиоксидантної системи та редокс-потенціалу крові корів $(\mathbf{M} \pm \mathbf{m}, \mathbf{n}=\mathbf{1 0})$

\begin{tabular}{|l|l|c|c|}
\hline № п/п & Показник & Контрольна група & Дослідна група \\
\hline \multicolumn{2}{|c|}{ Показники перекисного окиснення ліпідів } \\
\hline 1 & $\begin{array}{l}\text { Гідроперекиси ліпідів, відн. } \\
\text { од./мл }\end{array}$ & $3,82 \pm 0,42$ & $5,67 \pm 0,62$ \\
\hline 2 & Малоновий діальдегід, мкмоль/л & $1,27 \pm 0,18$ & $1,88 \pm 0,21^{*}$ \\
\hline \multicolumn{4}{|c|}{ Показники активності антиоксидантного захисту } \\
\hline 3 & Глутатіон загальний, ммоль/л & $1,32 \pm 0,17$ & $1,42 \pm 0,19$ \\
\hline 5 & Глутатіон відновлений, ммоль/л & $0,89 \pm 0,09$ & $0,65 \pm 0,08$ \\
\hline 6 & Глутатіон окислений, ммоль/л & $0,43 \pm 0,05$ & $1,77 \pm 0,08^{*}$ \\
\hline 7 & $\begin{array}{l}\text { Активність глутатіонредуктази, } \\
\text { мкмоль/хв./ г білка }\end{array}$ & $1,82 \pm 0,17$ & $+12 \pm 4,6$ \\
\hline
\end{tabular}

Примітка: ${ }^{*}-\mathrm{p}<0,05$

Порушення співвідношення між відновними та окисленими формами глутатіону, накопичення органічних перекисів призвело і до зміни значень редокспотенціалу, так у тварин дослідної групи більшість зразків мала негативні значення, тоді як у тварин дослідної групи всі значення редокс-потенціалу мали позитивні значення. Зміщення редокс-потенціалу у позитивний бік свідчить про накопичення окислених еквівалентів, які не компенсуються відновним резервом.

Збільшення редокс-потенціалу є надзвичайно небезпечним, оскільки за таких умов порушується електричний заряд мембран клітин, зменшується рухливість клітин крові, їх кооперація.

\section{Висновки}

Таким чином, утримання корів на територіях 3 комплексом несприятливих екологічних умов: підви- щеною щільністю радіоактивного забруднення, дефіцитом мінеральних елементів призводить до зростання інтенсивності процесів перекисного окиснення ліпідів, накопичення у крові гідроперекисів ліпідів та малонового діальдегіду на 48\% порівняно до таких у крові корів, що утримувались на екологічно благополучних територіях.

Активність глутатіонової ланки антиоксидантної системи у крові корів в умовах постійного впливу інкорпорованих радіонуклідів суттєво знижена, що проявляється у зменшенні відновної часки глутатіону на $73 \%$ та збільшення частки окисленої форми на 79\%, що свідчить про дефіцит відновного потенціалу крові тварин.

У корів, що утримувались у екологічно несприятливих умовах, редокс- потенціал змінюється, набуваючи позитивних значень, що свідчить про накопичення у крові окислених продуктів та дефіциту відновних еквівалентів. 
Перспективи подальших досліджень. Планується дослідження інших показників перекисного окиснення та антиоксидантної системи корів, зокрема визначення активності супероксиддисмутази, концентрації церулоплазміну та загальної антиоксидантної активності. Плануються дослідження динаміки редокспотенціалу крові у залежності від віку, фізіологічного стану тварини, складу раціону.

\section{Бібліографічні посилання}

Gavrilov, V.B., Gavrilova, A.R., Mazhul, L.M. (1987). Analiz metodov opredeleniya produktov perekisnogo okisleniya lipidov $\mathrm{v}$ syivorotke krovi po testu $\mathrm{s}$ tiobarbiturovoy kislotoy. Voprosyi med. himii. 1, 118 - 122 (in Russian).

Gavrilov, V.B., Mishkorudnaya, M.I. (1983). Spektrofotometricheskoe opredelenie soderzhaniya gidroperekisey lipidov v plazme krovi. Lab. delo. 3, 33-35 (in Russian).

Muhutdinova, F.I. (2015). Sostoyanie aktivnosti protsessov perekisnogo okisleniya lipidov i soderzhanie komponentov antioksidantnoy zaschityi v limfe i krovi pri eksperimentalnoy lihoradochnoy reaktsii. Sovremennaya meditsina: aktualnyie vopros- yi: sb. st. po mater. XLVIII-XLIX mezhdunar. nauch.-prakt. konf. -Novosibirsk, SibAK, 10, 11(43) (in Russian).

Kondrahin, I.P. (2004). Metody veterinarnoy klinicheskoy laboratornoy diagnostiki: Spravochnik. M.: Kolos (in Russian)

Rusak, V.S., Chala, I.V. (2015). Redoks-potentsial i vmist glutationu krovi koriv pri hvorobah pechinki. Visnik ZhNAEU. 1(49), 267-271 (in Russian).

Tolpyigina, O. (2012). Rol glutationa v sisteme antioksidantnoy zaschityi (obzor). Byulleten Vostochno sibirskogo nauchnogo tsentra. 2(84), 178-181 (in Russian).

Filipenko, G.V. (1996). Perekisnoe okislenie lipidov i fermentyi antioksidantnoy sistemyi pecheni pri deystvii ioniziruyuschego izlucheniya razlichnyih gepatotrofnyih povrezhdayuschih faktorov: avtoref. dis. na soiskanie nauchnoy stepeni kandidata meditsinskih nauk, spetsialnost 03.00.04. - biohimiya (in Russian).

Anderson, M.E. Meister, A. (1989). Glutathione monoesters. Analitic biochemistry. 183, 16-20.

Стаття надійшла до редакиії 28.09.2016 